DOI: https://doi.org/10.18485/philologia.2020.18.18.11 UDK: 821.111(73)-31.09 0ster P.

\title{
- KRIZA REPREZENTACIJE: POTRAGA ZA JEZIKOM U ROMANU GRAD OD STAKLA POLA OSTERA
}

\author{
ALEKSANDRA Z. STOJANOVIĆ1 \\ Univerzitet u Kragujevcu \\ Filološko-umetnički fakultet \\ Kragujevac, Srbija
}

Cilj rada jeste da predstavi roman Grad od stakla Pola Ostera u kontekstu pojmova traga i razlike Žaka Deride. Istražićemo način na koji se pojam znaka promenio od inicijalne ideje koju je postavio F. D. Sosir do znaka razigranog središta Ž. Deride. Centralna ideja u ovakvoj analizi jeste ideja izlomljenog znaka, odnosno znaka u kome je došlo do pucanja veze između označitelja i označenog i udvajanja označitelja, usled čega se javlja kriza reprezentacije. Pojmovi autorstva, naracije i identiteta dovedeni su u pitanje u poststrukturalizmu usled promene odnosa prema tekstu i samom jeziku. Analizom tekstualnog sveta ovog romana, autor nastoji da pokaže u kojim oblicima se javlja jezik, koja je njegova funkcija i koliki uticaj on ima na razvoj likova.

Ključne reči: Ž. Derida, trag, razlika, jezik, kriza, identitet, tekstualnost, Pol Oster.

\section{POJAM ZNAKA PREMA FERDINANDU DE SOSIRU}

Teorijsko polazište rada biće koncept znaka kako ga je ustanovio Ferdinard de Sosir u svom delu Kurs opšte lingivistike. Polazeći od pojma znaka, ispitaćemo kakav je uticaj Sosirova teorija imala na književnu analizu, pre svega na književnu dekonstrukciju poststrukturaliste Žaka Deride. Sosir navodi da „lingvistički znak ne spaja stvar sa imenom, već pojam sa akustičnom slikom. Ova slika nije materijalan zvuk, čista fizička stvar, već psihički otisak toga zvuka, predstava koju nam o njemu daje svedočanstvo naših čula" (Saussure 1969: 83-84). Već u ovoj definiciji možemo primetiti da ne postoji direktna veza između predmeta koji imenujemo, ili o kome mislimo, i njegove fizičke realizacije u svetu već mi u glavi imamo samo pojam te stvari, naime njenu

1 Kontakt podaci (Email): sandra.stojanovic95@hotmail.com 
reprezantaciju. Sosir zadržava termin znak ali termine pojam i akustična slika zamenjuje terminima označeno i oznaka². Jedna od glavnih karakteristika znaka jeste njegova proizvoljnost, to jest, činjenica da je znak zasnovan na konvenciji. Možemo govoriti i o motivisanosti jednog znaka koja se može definisati kao proizvoljnost u odnosu na označeno, sa kojim nema nikakve prirodne veze u stvarnosti. Međutim, Sosir navodi dva prigovora koji nam govore protiv nemotivisanosti jezičkog znaka, a to su primeri onomatopeje i uzvika. Kod ovih reči može postojati prirodna veza između oznake i označenog, gde zvuk zaista jeste u vezi sa rečju koja ga opisuje. Domen Sosirovog istraživanja bili su konvencionalni znaci među kojima nema nikakve prirodne veze niti urođenih karakteristika.

Sosir ističe: „Može se, na primer, reći da promene u jeziku nisu vezane za smenu generacija, koje ne stoje jedna nad drugom kao fioke komode, već se mešaju, uzajamno prožimaju i sadrže individue svih uzrasta" (Saussure 1969: 90). Dakle, Sosir objašnjava da može doći do promena u jeziku, ali je potrebno dosta vremena i postepenog mešanja da bi se one postigle. Pojedinac ne može izvršiti reformu jezika i svaki takav pokušaj biće dočekan neuspehom. „Čovek koji bi imao pretenziju da sačini nepromenljiv jezik, koji bi potomstvo imalo da prihvati takav kakav je, ličio bi na kvočku koja je izlegla pačje jaje: jezik koji je on stvorio bio bi, hteo-ne hteo, ponesen strujom koja nosi sve jezike" (Saussure 1969: 95). Način na koji se vrše ove promene najčešće su na fonetskom nivou oznake ili promene koje "uvek dovode do pomeranja odnosa između označenog i oznake" (Saussure 1969: 93). Kasnije ćemo kod Deride kao i drugih teoretičara poststrukturalizma i postmoderne kulturne logike, poput Žaka Lakana i Fredrika Džejmsona, videti da je upravo pomeranje tog odnosa ono na čemu se zasnivaju njihove teorije kao i glavna razlika između strukturalizma i poststrukturalizma. Promena u načinu shvatanja jezika i njegove sposobnosti označavanja suštinska je promena koja se odigrala na prelasku između ove dve teorijske matrice i bitno će uticati na identitet pojedinca i celog društva.

\section{POJAM ZNAKA ŽAKA DERIDE}

Pošto smo predstavili pojam znaka Ferdinada de Sosira, prelazimo na poimanje znaka, oznake i označenog u teorijama Žaka Deride. Polazeći od teorije F. de Sosira, Derida izvrće sam pojam vršeći dekonstrukciju i predstavljajući nam znak koji više nije sačinjen od oznake i označenog, kao što je bilo kod Sosira, već od dva označitelja. Prema viđenju jezika ž. Deride označitelj nije u direktnoj vezi sa označenim i ne postoji podudaranje između označenog i označitelja. Derida tvrdi da nam značenje nije jasno istog trenutka kada pročitamo neki znak. Značenje se stalno kreće lancem označitelja i nikada ne možemo odrediti njegovu tačnu lokaciju, jer nikada nije vezana za jedan konkretan znak. Došlo je do prekida u lancu označavanja i oznaka više nije ta koja upućuje na označeno već postoji udvostručena predstava, označitelj koji ukazuje na drugog označitelja. „Označitelj označitelja, naprotiv, opisuje kretanje govora: u njegovu porijeklu, zasigurno, ali već se naslućuje da se porijeklo, kojeg se struktura tako razlaže

2 U Sosirovom originalnom tekstu ovi pojmovi se navode kao signifié i significant. 
- označitelj označitelja - uvodi i briše u svom vlastitom stvaranju. Označeno tu djeluje uvijek već kao označitelj" (Derrida 1976: 14).

U Struktura, znak i igra u diskursu humanističkih nauka, Derida govori o „događaju” koji se odigrao na prelasku iz strukturalizma u poststrukturalizam a to je pomeranje središta strukture i njena zamena igrom. Autor saopštava da " [...] sve do tog događaja koji bih želio razmotriti, struktura, ili još bolje, strukturalnost strukture, uvijek je bila neutralizirana, reducirana, iako je uvijek bila na djelu: gestom koja joj je davala središte, dovodila do točke prisutnosti, čvrstog podrijetla. [...] Ipak, središte i zatvara igru koju otvara i omogućava" (Derrida 2007: 297). Pomeranje središta jeste jedna od glavnih odlika poststrukturalističkog i postmodernističkog razmišljanja time što omogućava da dođu do izražaja strukture koje su prethodno bile skrajnute. Više u centru pažnje nije prisustvo već se sada sve posmatra kroz odsustvo i supstitucije prisutnog. U toj igri značenja koja više nema stabilno središte dolazi do stalnog odlaganja značenja. Tada stupa na snagu pojam razlike.

Pojam razlike potiče od francuskog glagola différer koji označava razliku između pojmova u smislu distinkcije i nekompatibilnosti sa drugim stvarima. Derida uvodi pojam différance napisan sa slovom a koji ne treba mešati sa pojmom différence napisanom slovom e. „Naziv diferancija dajemo istosti koja nije potpuno ista: pisanjem nečujnog slova $a$ otvara nam se mogućnost da ukazujemo na razlikovanje kao na vremensku i prostornu pojavu i pokret koji je u osnovi strukture svake disocijacije ${ }^{3 "}$ (Derrida 1973: 129). Prema predlogu Novice Milića, u daljem tekstu ćemo upotrebljavati izraz diferancija da uputimo na pojam différance Žaka Deride, dok će pojam diferencije (différence) u svom izvornom značenju ostati oslovljen razlikom. Diferancija nije pojam, niti Derida želi da ga mi shvatimo kao takvog. Kako Novica Milić navodi, dva razloga zašto diferancija nije pojam jesu što ona nema središte ni granice i ne podleže pojmovnim pravilima. Diferancija se odnosi na brisanje, odlaganje, izmicanje značenja. Njena suština sadržana je u samom formulisanju reči zamenom slova e slovom a koje ne utiče na izgovor reči već je samo vidljiva u pisanju: „Najpre, diferancija kao reč nastaje brisanjem, uklanjanjem jednog e u diferenciji i zamenom u a. Kao reč, to je 'reč' brisanja, 'tihog upisivanja', kako kaže Derida, pre nego isticanja ili govora" (Milić 2005: 33).

Kako tumačiti pojam znaka u kontekstu diferancije? „Znakovi predstavljaju sadašnjost u njenom odsustvu; oni zauzimaju mesto sadašnjeg"4 (Derrida 1973: 138). Kretanje znaka odlaže njegovo značenje i tako se formira u igri njegovih označitelja. "Označitelj nikada nije prisutan sam po sebi na način koji bi mogao da se odnosi samo na njega. Svaki koncept nužno je i suštinski pripisan lancu ili sistemu značenja unutar kojeg se odnosi na druge koncepte, sistematskom igrom diferancija"s (Derrida 1973:

3 "We provisionally give the name différence to this sameness which is not identical: by the silent writing of $a$, it has the desired advantage of referring to differing, both as spacing/temporalizing and as the movement that structures every dissociation."

4 "Signs represent the present in its absence; they take the place of the present."

5 "The signified concept is never present in itself, in an adequate presence that would refer only to itself. Every concept is necessarily and essentially inscribed in a chain or a system, within which it refers to another and to other concepts, by the systematic play of differences." 
140). Stoga, ono što mi smatramo diferancijom u kontekstu znaka će biti realizovano kao pomeranje iigra koja stvara značenje. „Diferancija je ono što omogućava pomeranje označavanja samo u slučaju da se svaki element za koji kažemo da je 'prisutan' odnosi na nešto osim sebe, ali istovremeno zadržava oznaku prošlog elementa i već dozvoljava da mu značenje popuni odnos budućim elementom"6 (Derrida 1973: 142). U tom smislu govorimo o narednom ključnom pojmu analize predstavljene u radu, a to je pojam traga. Ovaj trag odnosi se i na prošlost i na budućnost, i svoje značenje konstituiše na osnovu svega što jeste i što nije - na osnovu prisutnog i odsutnog.

\section{RASKID U LANCU OZNAČITELJA}

Prilikom istraživanja romana Grad od stakla uočavamo najpre raskid u lancu označitelja, a zatim i promenu u samom znaku. Umesto da oznaka nekog pojma upućuje direktno na njenog označitelja, sada dolazi do dodatnog koraka u procesu interpretacije. Označitelj se može definisati sledećim iskazom: „označitelj je ono što predstavlja subjekt, za koga? - ne za drugi subjekt, već za drugog označitelja" (Lacan 1986: 211). Lakan smatra da „treba operirati sa dva označitelja, jer se subjekt u otuđenje može pritisnuti uza zid samo pomoću dva [označitelja]" (Lacan 1986: 252). Problem kod situacije u kojoj postoje dva označitelja jeste u tome što se oba označitelja nalaze na istoj ravni postojanja u mislima, nijedan nije važniji od drugog. Oba označitelja predstavljaju samo ideju nečega, ne dolazeći do suštine same stvari. Ovakvo stanje se može pripisati "nesvedivom i besmislenom karakteru lanca označitelja” (Lacan 1986: 226). Jednostavnost jezika bila bi u tome što svaki pojam ima jasno određenu oznaku koja ukazuje samo na jednog označitelja i time ne izaziva dvosmislenosti i zabune. Kako je to nemoguće, treba naći način da se pomirimo sa sistemom reprezentacija kakav nam je dat. Džejmson navodi:

Prema ovom novom shvatanju, značenje izvedeno iz kretanja jednog označitelja ka drugom označitelju: ono što mi nazivamo označenim - značenje ili pojmovni sadržaj jednog iskaza - sada se posmatra kao efekat značenja, kao objektivni privid značenja stvoren međusobnim odnosom označitelja. Kada ta veza popuca i ovaj označiteljski lanac se prekine, imamo šizofreniju u obliku polomljenih, razdvojenih i nepovezanih znakova. (Jameson 2012: 508)

Umesto da upućuje na označeno, sada oznaka upućuje na drugog označitelja terajući ljude da sami rekonstruišu značenje znaka kroz tragove date u igri i stalnom pokretu označitelja, što izaziva nesklad i fragmentarnost subjekta. U dobu kada je znak toliko nestabilan u svom upućivanju, nije neobično naići na izlomljene ličnosti, izgubljene u prostoru, u potrazi za značenjem i smislom - što bi Lakan nazvao šizofrenim ličnostima. Takve ličnosti više nemaju predstavu o stvarnosti niti mogu da vide pravu

6 "Difference is what makes the movement of signification possible only if each element that is said to be 'present,' appearing on the stage of presence, is related to something other than itself but retains the mark of a past element and already lets itself be hollowed out by the mark of its relation to a future element." 
sliku stvari, jer je ona sakrivena iza mora označitelja. Dejvid Harvi takođe govori o procepu u ličnosti do kojeg dolazi usled prekida u lancu označitelja navodeći da je „efekat ovakvog sloma u lancu označitelja da svede iskustvo na niz čistih i nepovezanih sadašnjosti"7 (Harvey 1989: 53). Stvaranje ovakvog odnosa prema jeziku će dovesti do otuđenja od njega samog. Inherentna potreba čoveka jeste da traži smisao u haotičnom i fragmentarnom okruženju, jer ima potrebu za jednostavnošću označavanja. Prilikom prelaska iz strukturalizma u poststrukturalizam znak gubi svu transparentnost i put do njegovog otkrivanja postaje sve duži i kompleksniji. Lanac označitelja dodatno nas udaljava od same stvari. Sve ovo dovelo je do jedne opšte krize reprezentacija u postmodernizmu, koja se najbolje uočava upravo na planu jezika.

\section{AUTOR U POSTSTRUKTURALIZMU}

Poststrukturalizam ističe prirodu subjekta kao stvaraoca kojije često fragmentaran i kontradiktoran u svojim delima. Takav subjekt ne razume o čemu govori, a i ne mora razumeti, jer se nalazi usred krize reprezentacija kada više nije poznato šta se na šta odnosi. Kaler ističe da se „skrenula pažnja sa autora kao izvora i sa dela kao objekta i, umesto toga, usredsredila na dva korelativna spleta konvencija na pisanje kao instituciju i na čitanje kao delatnost" (Culler 1990: 197). Napisano delo počinje da postoji kao takvo tek kada bude pročitano. Čitaoci daju značenje tekstu tumačenjem tragova u njemu. Pripisati nekom delu autora znači odrediti mu granice, a priroda znaka u poststrukturalizmu takva je da zahteva slobodu tumačenja, slobodu kretanja i stalnog odlaganja značenja. U skladu sa karakteristikama ovog perioda, tekst postaje višeglasan i dobija onoliko autora koliko je čitalaca - umnožavaju se označitelji teksta.

U poststrukturalističkim tekstovima postaje nevažno ko je autor, ko je narator, ko govori. Svaki glas koji se javlja u tekstu predstavlja trag u deridijanskom smislu i time ulazi u igru značenja i širi mogućnost tumačenja dela. Pored različitih pomešanih diskursa i višeglasja, tekst može sadržati i tragove drugih tekstova. Linda Hačion definiše intertekstualnost kao nešto što od čitaoca zahteva „ne samo prepoznavanje tekstualizovanih tragova i književne i istorijske prošlosti već takođe i svest o onome što je-putem ironije-sa tim tragovima učinjeno. [...] Knjige uvek govore o drugim knjigama, i svaka priča kazuje priču koja je već kazivana" (Hutcheon 1996: 214). Intertekstualnost nije slučajna već ima svrhu da tragovima navede čitaoce koji su ih prepoznali na određena tumačenja datog teksta. Tekst u kome uočavamo intertekstualnost uklapa se u koncept znaka kakav nam je predstavio Derida - umesto da znak u tekstu upućuje na nešto konkretno i nešto iz stvarnog sveta, on nas navodi na druge tekstove, to jest druge označitelje i tako formira lanac označitelja koji se ne može prekinuti.

U romanu Grad od stakla javlja se osvrt na sam jezik koji se upotrebljava. U tom smislu možemo prepoznati postojanje metajezika koji Džejmson definiše kao „formu samosvesti u oblasti jezika, to je jezik koji govori o sebi, skup znakova čije je označeno po sebi sistem znakova" (Jameson 1974: 356). Ovaj jezik ne upućuje na konkretne

7 "The effect of such a breakdown in the signifying chain is to reduce experience to a 'series of pure and unrelated presents in time." 
predmete već sam na sebe u čemu prepoznajemo „označitelje označitelja”. Pričanje priča javlja se kao potreba za uspostavljanjem značenja i pozicije subjekta u svetu. Pričamo da bismo razumeli svoje okruženje, zbivanja oko nas, interakcije sa drugima, a pre svega da bismo razumeli sebe. Nemogućnost izražavanja sopstvene priče dovodi do fragmentarnog i otuđenog subjekta. Uloga jezika u formiranju ličnosti je značajna. Način na koji jezik učestvuje u konstituisanju nečijeg identiteta jeste upravo taj što kroz njega učimo o svetu i sebi, stupamo u interakciju sa drugima. Kada je okruženje izlomljeno i nepotpuno onda će čovek imati poteškoća sa odabirom odgovarajućeg jezika za izražavanje svojih misli. Kao posledica, jezik postaje fragmentiran. Jezik u kome dolazi do tolikog umnožavanja značenja i lanaca beskrajnih označitelja neminovno će odvesti u haos u kome će ljudi početi da gube pojam o svetu oko sebe kao i sebi samima.

\section{GRAD OD STAKLA}

Njujorška trilogija Pola Ostera sastoji se iz tri romana: Grad od stakla, Duhovi, Zaključana soba. Svaka od navedenih knjiga bavi se tematikom identiteta, zamućenih granica stvarnosti i jezičkom reprezentacijom. U ovom radu bavićemo se samo knjigom Grad od stakla, jer je u njoj najjasnije prikazana kriza reprezentacije i prekid u lancu označitelja. Dok sva tri romana prikazuju slične ideje, prvi deo u centar pažnje stavlja sam jezik i njegov razvoj od pojma znaka kakav uočavamo u dekonstrukciji jezika Žaka Deride i uvođenja pojmova poput diferancije i traga. Primenom poststrukturalističkih teorija jezika, rad teži da prikaže ovaj roman kao fizičku reprezentaciju teorija poststrukturalizma u kojoj jasno uočavamo deridijanske koncepte jezika.

\subsection{POTRAGA ZA IDENTITETOM DANIJELA KVINA}

Kvin uze Marka Pola i krenu ispočetka da čita prvu stranu. 'Viđene stvari ćemo navoditi onako kako smo ih videli, one što smo čuli onako kako smo ih čuli, tako da naša knjiga bude tačan zapis, oslobođen bilo kakvih izmišljotina. I svi oni koji čitaju ovu knjigu ili slušaju iz nje, mogu to da čine s punim poverenjem jer se u njoj ne nalazi ništa drugo do sama istina.' Baš kad je Kvin počeo da se udubljuje u ove rečenice, da krhka uveravanja koja se u njima nalaze prevrće po svom umu, zazvonio je telefon. (Auster 2017: 12)

Kvinova priča počinje telefonskim pozivom upućenim detektivu Polu Osteru, čiji identitet Kvin preuzima u daljem toku romana. Činjenica da on čita o avanturama Marka Pola i priprema se da "uplovi" u imaginarni tekstualni svet u trenutku kada je zazvonio telefon postavlja nam okvire tumačenja ovog dela. Poziv i sve što će uslediti nakon njega posmatraćemo kao jednu priču, tekstualnu konstrukciju čije značenje treba da se odgonetne. Poput sveta Marka Pola, svet Danijela Kvina takođe predstavlja jedan jezički univerzum. Citirajući deo romana o verodostojnosti i istinitosti priče, autor implicira da za Grad od stakla takođe važe navedeni principi. Takva izjava dovodi u pitanje ne samo autorstvo dela već i kredibilitet njegovog naratora. Danijel Kvin je 
pisac koji piše detektivske romane o liku Maksu Vorku pod maskom svog pseudonima Vilijama Vilsona. Kvin je ličnost koja sama po sebi implicira heteroglosiju i nikada nismo sigurni šta je zapravo on napisao, šta je pravo oličenje njegove ličnosti, a šta imaginacija i projektovanje želja u književni tekst. „U trijadi Kvinove ličnosti, Vilijam Vilson predstavljao je neku vrstu trbuhozborca. Sam Kvin bio je lutka, a Vork je bio animirani glas koji je čitavom poduhvatu davao smisao" (Auster 2017: 11). Sve ovo dovodi čitaoce u nedoumicu oko pravog identiteta Danijela Kvina što se dodatno komplikuje kada on reši da preuzme identitet i slučaj privatnog detektiva Pola Ostera čiji je telefonski poziv slučajno dobio. Nije slučajnost što se književni lik zove isto kao i autor romana što dovodi do daljeg zamućenja granica između fikcije i stvarnosti, čoveka i književnog lika, autora i naratora. Čitaocima se otvara čitav niz interpretacija i potencijalnih tumačenja ovih likova, jer središta u naraciji više nema. „Sve dobija suštinski značaj; središte knjige pomera se sa svakim događajem koji ga tera napred. Središte je, tako, svugde, i nikakve konture nije moguće izvlačiti sve dok se ne dođe do kraja knjige" (Auster 2017: 13). Postoji mnoštvo glasova, naratora i priča koje mi kao čitaoci možemo izabrati da pratimo, ali ono što važi u slučaju bilo kog našeg izbora jeste da se značenje stalno menja. Središte se pomera i ne može se odrediti u sadašnjosti već samo prema budućim interpretacijama, kako nam govori pojam diferancije. Značenje dela, njegovo autorstvo i naracija stalno se odlažu, prikrivaju i otkrivaju u zavisnosti od datih konteksta. Kvina možemo posmatrati kao jedan jezički znak koji poseduje više realizacija, odnosno više označitelja u vidu svih ličnosti koje on preuzima na sebe. Tragovi svih ličnosti sadržani su u ovom jednom liku koji zbog toga doživljava krizu reprezentacije svog identiteta. Slika u ogledalu je nejasna, i za razliku od Lakanovog stadijuma ogledala, u ovom slučaju ogledalo je polomljeno i reflektuje izlomljene i nejasne slike. „A zatim, najvažnije od svega: podsećati se ko sam ja. Podsećati se ko bi trebalo da jesam. Ne mislim da je ovo igra. S druge strane, ništa nije jasno. [...] Moje ime je Pol Oster. To nije moje pravo ime" (Auster 2017: 41). Kao Pol Oster Kvin se osećao "neuporedivo lakše i slobodnije” (Auster 2017: 49), jer je bio oslobođen svojih misli i svog života, „kao da nije više morao da hoda naokolo s teretom sopstvene svesti" (Auster 2017: 49). Preuzimajući označitelja koji je različit od sopstvenog imena, čovek je oslobođen svojih životnih priča, svojih patnji i ne nosi teret svog imena. Kaler tvrdi da imenovanje književnog lika igra važnu ulogu u strukturalističkoj analizi dela, jer lično ime podrazumeva prikupljanje osobina jednog čoveka i „uverenje da ove osobine prikupljene od početka do kraja teksta, mogu da se povežu u jedno i da obrazuju celinu koja je veća od zbira sastavnih delova" (Culler 1990: 350). Pored toga, lično ime predstavlja našu vezu sa svojom porodicom koja se može gledati kao sistem srodnih znakova, dok je samo ime označitelj ličnosti. Imena nas u tom smislu definišu i svako oslobađanje tereta tog označitelja izaziva slobodu da se istražuje ličnost i isprobavaju drugi označitelji. Međutim, koliko pruža slobodu toliko je preuzimanje Osterove ličnosti kobno za Kvinov identitet, jer je Oster samo jedan nepotpun znak - polomljen i nedefinisan, označitelj kome fali označeno. Kada je preuzeo taj identitet Kvin se osećao kao „čovek bez unutrašnjosti, čovek bez misli” (Auster 2017: 59). Preuzevši ime Pola Ostera na sebe, Kvin je prihvatio tu ulogu i odbacio sve prethodne označitelje, naime svoje ime, imena V. Vilsona i M. Vorka. Vremenom postaje Pol Oster u svojim mislima i ponašanju, a Kvin se gubi i ostaje samo kao trag u označavanju, odsustvo nekada prisutne ličnosti koja je izgubljena u moru označitelja. 
Tragovi u samom tekstu odnose se i na mnoštvo intertekstualnih aluzija i referenci koje možemo zapaziti, od kojih je najdominantnija uvođenje Don Kihota u tekst. Danijel Kvin deli inicijale sa čuvenim fikcionalnim likom M. Servantesa. Mišel Fuko u svom delu Riječi i stvari opisuje Don Kihota kao nekoga ko „bezbroj puta prelazi preko nje, ne prekoračivši nikad jasnu granicu razlike i ne dospjevši do srca identiteta. On sam, međutim, liči na neki znak. Dug, mršav grafički znak poput slova, kao da upravo izlazi iz otvorene knjige. Čitavo njegovo biće jeste samo jezik, tekst, odštampani listići, već prepisana priča" (Foucault 1971: 111).

Danijel Kvin se kreće u tekstu, pliva u jeziku i moru neodređenosti i pokidanih Ianaca označitelja. On ne zna ko je, šta ga sačinjava, na šta upućuje niti na kojoj ravni zapravo postoji. Don Kihot, poput našeg Danijela Kvina, jeste junak koji ne stupa u klasičnu avanturu koju bi čitaoci očekivali, uprkos odrednicama žanra romana kojem pripada. Njegovo je putovanje kroz tekst, a njegova avantura može se shvatiti kao borba za čistotom i istinom jezika. Prema Fukou „taj podvig treba da bude dokaz: on se ne sastoji u stvarnom trijumfu - zbog toga pobjeda u osnovi nije ni velika - nego u transformisanju stvarnosti u znak. U znak po kome se utvrđuje da znaci jezika odgovaraju samim stvarima" (Foucault 1971: 112).

Na kraju poslednjeg poglavlja Osterovog romana uočavamo promenu iz trećeg lica naracije u prvo lice. Narator nam saopštava da je sve što je prethodno ispričano zasnovano samo na zapisima iz Kvinove crvene sveske i da se ništa ne može sa sigurnošću tvrditi o samim događajima niti o njihovom raspletu. Čitava priča koja nam je predstavljena jeste tekst iz sveske, zapisi jedne izgubljene ličnosti čiji život nije bio ništa više do jezičke konstrukcije.

\subsection{JEZIČKI LAVIRINT NJUJORKA}

Usled raskida u lancu označitelja i promene odnosa znaka u poststrukturalizmu, Danijel Kvin je pronašao sebe u haotičnom jezičkom univerzumu nepoznatih odrednica iz koga ne može da pobegne. Dolazi do rascepa ličnosti i ono što je potrebno jeste da se opet uspostavi stabilna pozicija u jezičkom koordinatnom sistemu. „Usled ovakve rascepljenosti, humani subjekt je u stanju konstantnog kretanja (fluksa), odnosno permanentnog ekstazisa, zauvek u potrazi za ukradenom istinom i čistotom jezičke reprezentacije kakva je postojala pre Adamovog izgnanstva" (Lojanica 2012: 170). 0 pojmu čistote jezičke reprezentacije u romanu biće reči u narednom poglavlju.

U skladu sa navedenom idejom da se u kretanju konstituše identitet $i$ da je ono pokušaj povratka izgubljenog, možemo posmatrati šetnje Danijela Kvina kao način ponovnog uspostavljanja celovitosti svog polomljenog znaka. Kvin je voleo da šeta i šetao je uvek kada bi se za to pružila prilika, ne znajući kuda će ga noge odvesti:

Njujork je predstavljao neiscrpan prostor, lavirint beskrajnih koraka, i bez obzira na to koliko bi hodao, bez obzira na to što je dobro upoznao njegove kvartove i ulice, grad je u njemu uvek izazivao osećaj izgubljenosti. Izgubljenosti ne samo u gradu, nego isto tako i unutar sebe. Svaki put kad bi pošao u šetnju, osećao bi kako napušta sebe [...] Kretanje je predstavljalo suštinu, radnja stavljanja jednog stopala ispred drugog mogućnost da sledi tok sopstvenog tela. Od besciljnog lutanja sva mesta 
postala su ista, i nije mu bilo važno gde se nalazi. U svojim najboljim šetnjama, mogao je da oseti kako se ne nalazi nigde. Njujork je bio to nigde koje je sagradio oko sebe, i shvatio je da nema nameru da ga ikad napusti. (Auster 2017: 10)

U ovom radu želimo predstaviti Njujork ne kao lavirint fizičkog prostora već kao jedan jezički lavirint u kome osećaj izgubljenosti stvara bezbroj znakova i njihovih upućivanja na različite označitelje. U tom pokretu mi uvek jurimo značenje koje nam stalno izmiče i odlaže se. Ne možemo doći do njegove suštine, jer je ona u konstantom fluksu, jezik se stalno menja i sa njim i način na koji percipiramo svet oko sebe. Međutim, Kvinovo besciljno lutanje gradom dobija svrhu i cilj onda kada počne da prati Pitera Stilmana. Dok je lutanje predstavljalo neku vrstu isključivanja uma i prepuštanja kontrole gradu, praćenje Stilmana bilo je kretanje sa jasnim ciljem i određenom putanjom. Iako je Kvin nije znao u trenutku svog kretanja, ona je unapred bila određena Stilmanovim odlukama. Stilman ostavlja tragove svog kretanja koje Kvin mora da prati kako bi došao do značenja. Kvinu je stalno „izmicao smisao onoga što vidi" (Auster 2017: 56), jer se smisao poput traga stalno skrivao i otkrivao u igri, uvek na kraju nestajući. Kvin i Stilman obojica poseduju crvene sveske koje nose sa sobom i u kojima beleže nešto tokom svog kretanja. Kvin počinje detaljno da beleži Stilmanovo kretanje, praveći mape u nadi da će mu one pružiti neko središte i razjasniti značenje Stilmanovih dela. Kad Kvin okrene prazan list svoje sveske sa namerom da zapiše korake čoveka koga prati, on nije prazan. Taj list papira već je ispisan i ispunjen tragovima kretanja, predodređeno je šta će na njemu pisati. Još kada je kupovao svesku činilo mu se „kao da ga nešto u vezi sa njom privlači - kao da je baš njena sudbina na celom svetu bila da sadrži ove reči iz njegovog pera" (Auster 2017: 40). Praćenjem Stilmana Kvin je počeo da živi njegovim životom, hoda njegovim stopama, da prati njegove tragove i da juri za značenjem koje mu stalno izmiče. Kada je prestao da prati Stilmana, protagonista je izgubio deo svoje ličnosti. Tokom te dve nedelje njih dvojica su predstavljali ujedinjeni znak, čiji su se delovi odjednom rascepili i odvojili, gubeći svako značenje. Kvinu se činilo „kao da je izgubio polovinu svog bića” (Auster 2017: 84). Gubljenje Stilmana za Kvina predstavljalo je gubitak svrhe, cilja, funkcije. U tom haosu i nesnađenosti, Kvin počinje opet da šeta gradom u nadi da će pronaći sebe ponovo i po prvi put koristi svesku da mapira svoje kretanje i pokuša da odredi svoj položaj i funkciju. Put ka pronalasku sebe je, u ovom slučaju, kroz pisani tekst - obeležavanjem svojih pozicija i misli u svesci Kvin namerava da povrati jedinstvo sopstvenog znaka. Kvinovo beleženje svakog svog koraka takođe se može posmatrati kao potreba za pričanjem svoje priče kako bi sebi razjasnio sopstveno postojanje.

Grad od stakla predstavljen nam je kao detektivska priča koja je u osnovi potpuno izvrnuta. Ne postoji zločin u konvencionalnom smislu već je učinjen zločin nad jezikom. Potraga za zločincem u ovom slučaju je potraga za značenjem jezika i za njegovom celovitošću. Ne postoji razrešenje misterije već samo veće zapadanje u vrtlog jezičkog univerzuma i gubljenje u tekstualnom lavirintu. Sve se svodi na pričanje priče, pisanje i sam tekt. Ističe se tekstualnost i bitna uloga koju jezik ima u životu i identitetu Ijudi. „Likovi koji se kreću tekstualnim univerzumom Njujorške trilogije Pola Ostera koncipirani su kao retoričke figure ili kao eksponenti postmodernističkih teorijskih matrica. Oni 'žive' u svetu koji je strogo omeđen: kao i za Deridu, ni za njih ne postoji 
ništa izvan teksta” (Lojanica 2012: 171). Likovi „umiru” tako što postaju deo teksta, gubi se svaki kontakt sa realnim svetom i ne preostaje im ništa osim da se stope sa gradom. "Stilman je nestao. Starac je postao deo grada. Postao je tačka, znak interpunkcije, cigla u beskrajnom zidu od cigala" (Auster 2017: 83). Ovime je naglašena tekstualnost samih likova. Grad je tekst i Stilman se zapravo izgubio u svom jeziku, izlomljenim i nejasnim mislima. Stilmanov nestanak predstavlja pobedu poststrukturalizma nad strukturalističkom koncepcijom jezičkog znaka, konačno kidanje lanca označitelja, trivijalizovanje znaka i zapadanje u ultimativnu krizu reprezentacije. Isto se dešava i sa Kvinom ubrzo nakon Stilmanovog nestanka, jer i on „baš kao da se stopio sa zidovima grada" (Auster 2017: 105). Obojica postaju šizofrene ličnosti prema Ž. Lakanu, odvojeni od svojih oznaka i dovedeni do gubljenja značenja. Svaki trag njihovog postojanja se gubi - broj Virdžinije Stilman više nije u funkciji, Kvin je izbačen iz svog stana - jedino što ostaje jeste Kvinov zapis događaja u crvenoj svesci što pokazuje da su oni nestali u tekstu.

\subsection{JEZIČKA REFORMA PITERA STILMANA - KONSTRUISANJE JEZIČKOG GRADA}

Zainterpretaciju problemajezika predstavljenih u romanu ključnasu tri lika-Danijel Kvin, Piter Stilman i njegov sin Piter Stilman Mlađi. Piter Stilman je svog sina izolovao od ostatka sveta i na devet godina zatvorio u prostoriju u kojoj vladaju potpuni mrak i tišina. Želeo je da izvrši eksperiment čiji je cilj bio da proveri da li će dete koje nije pod jezičkim uticajem okoline progovoriti "božanskim jezikom", onakvim koji je postojao pre pada Raja. Stilman je smatrao da čovekov pad predstavlja ujedno i pad jezika, jer su tada „imena odvojena od stvari; reči su se pretvorile u zbirku arbitrarnih znakova; jezik je otrgnut od boga" (Auster 2017: 43). Adam je imao zadatak da imenuje sve stvari i to je učinio na takav način da „te reči nisu jednostavno nakačene na predmete koje je video, one su otkrivale njihovu suštinu, doslovno ih oživljavale" (Auster 2017: 43). Sve to prestalo je da važi posle pada, kada je umesto imenovanja koje prati naturalističke teze nastupilo konvencionalističko shvatanje. Čistota Adamovog jezika uništena je i Stilman je smatrao da se ponovna utopija može postići samo preko reforme jezika. Želeo je povratiti stanje u kome označeno ima svog prirodnog označitelja, u kome ne postoji dvosmislenost i jezička iskvarenost. Stilman je bio opsednut mitom o Vavilonu, smatrao je da je izgradnja novog Vavilona ono čemu treba težiti. Fuko navodi:

U svom prvobitnom obliku, kada je ljudima bio podaren od boga, jezik je bio apsolutno izvjestan i providan znak stvari zato što im je ličio. [...] Da bi ljudi bili kažnjeni ta prozirnost je uništena u Vavilonu. Jezici se podijeliše i postaše netrpeljivi u onolikoj mjeri u kolikoj je bila izbrisana njihova sličnost sa stvarima, koja je bila prvi razlog postojanja jezika. Sve jezike koje poznajemo mi danas govorimo samo na osnovu te izgubljene sličnosti i u prostoru koji je ona ostavila praznim. (Foucault 1971: 108)

Dok su ljudi delili isti jezik tada su svi imali iste znake koji su imali isto označeno i iste označitelje. U jeziku u kome nastupa kriza reprezentacije situacija se menja i 
dolazi do raslojavanja značenja označitelja. Ne postoji prozirnost jezičkog znaka koja omogućava da svi imaju pristup istom značenju. Prava utopija bi bila kada bi svi opet govorili jezikom u kome postoji takav odnos unutar znaka, što znači da potencijalna utopija za Stilmana ne postoji kao mesto već kao pojam koji se može realizovati samo kroz reformu jezika.

Stilmanove ideje o stvaranju novog Vavilona izražene su u pamfletu koji je napisao Henri Dark ${ }^{8}$, za koga saznajemo da nije zapravo postojao već da je samo pseudonim pod čijom je maskom Stilman pisao ideje, za koje je smatrao da su previše delikatne da bi ih masa prihvatila. Značenje ovog imena leži u tome što je Stilman svog sina zatvorio u potpuni mrak kako bi dokazao valjanost svojih teorija i da je smatrao da će iz mraka proisteći čist i neiskvaren božanski jezik. Drugo značenje ovog pseudonima jeste to da deli inicijale sa likom Hampti Dampti iz poznate pesme za decu. ${ }^{9}$ H. D. se polomio usled pada, poput jezika i ostao je tako fragmentaran da ga je bilo nemoguće sastaviti. Stilman svoju misiju ispunjava tako što, hodajući gradom, svojom putanjom ispisuje slova "TOWER OF BABEL". Time on ostavlja samo tragove koji nestaju neposredno nakon što nastanu i ne mogu se ni pronaći ni dešifrovati u svom prikrivanju. Međutim, Kvin beleži Stilmanove korake, ucrtava ih u svoju crvenu svesku i time materijalizuje njegov poduhvat. Osim toga što koracima ispisuje slova gradeći novu jezičku utopiju u svojim mislima, Stilman ispunjava još jedan zadatak tokom svojih šetnji. Naime, on sakuplja polomljene predmete, vodeći dnevnik o svemu što prikupi dajući im novi naziv. Glavno pitanje koje se povlači u ovom delu teksta jeste: da li se polomljeni predmeti koji više ne mogu vršiti svoju funkciju još uvek mogu nazivati istim imenom? To pitanje zapravo je pitanje označavanja, naime, da li je moguće da jedan označitelj obeležava dva označena, koja su u ovom slučaju predmet koji je u funkciji i onaj koji više ne vrši tu funkciju. Povlači se pitanje da li imenovanje zavisi od funkcije predmeta i šta dovodi do toga da nešto izgubi svoje ime. Kišobran iako je polomljen i više ne služi toj svrsi još uvek jeste taj predmet. U njemu postoji trag prethodne funkcije koja je trenutno odsutna, ali ipak prikazuje nekadašnje prisustvo. Slomljeni predmeti dovode do slomljenih predstava o tim predmetima, što naposletku dovodi do slomljenih misli koje uzrokuju krizu reprezentacije.

Kada Kvin prvi put vidi Pitera Stilmana Mlađeg on je obučen sav u belo. „Sve na Piteru Stilmanu bilo je belo. Bela košulja otkopčana oko vrata; bele pantalone, bele cipele, bele čarape. Naspram bledila kože, tanka bledožuta kosa, zbog čega je bio gotovo proziran, kao da se kroz plave vene ispod kože na licu moglo gledati" (Auster 2017: 19). Njegova prozirnost upućuje nas na transparentnost jezičkog znaka. Piter Stilman Mlađi govori na svoj način nakon što je proveo detinjstvo zatvoren u potpunom mraku,

8 Simbolika imena na engleskom jeziku leži u tome što ono znači mrak što se može povezati sa mrakom u kome je odrastao Piter Stilman Mlađi. Piter Stilman Stariji je smatrao da su mrak i tišina preduslov za razvijanje „čistog jezika”, jer su ljudi tako bezbedni od uticaja drugih govornika, stoga mogu formirati označitelje koji imaju prirodnu vezu sa predmetima iz svog okruženja.

9 Humpty Dumpty sat on a wall

Humpty Dumpty had a great fall

All the king's horses and all the king's men

Couldn't put Humpty together again 
bez ikakvog jezičkog modela. Model njegovog govora možemo videti na primeru opisivanja smrti majke, ostajanje sa ocem i zlostavljanje koje je usledilo: „Onda, nema majke. Ha, ha. Moj smeh je sada takav, stomak mi puca od brbljanja. Ha, ha, ha. Veliki otac kaže: nema veze. Sa mnom. Odnosno, s njim. Veliki otac velikih mišića, i bum, tras, bum. Bez pitanja sada, molim" (Auster 2017: 20). Govor Pitera Stilmana Mlađeg je nepovezan, izlomljen i nesiguran. Često upotrebljava onomatopejske reči kako su one jedine koje imaju direktnu prirodnu vezu sa svojim označiteljem: „Vimbliklik kramblčo beloo. Klak, klica, stoličica. Muka buka, fleklmekl, čomama. Ja, ja, ja. Izvinite. Jedino ja razumem ove reči" (Auster 2017: 21). Da bi komunikacija bila moguća neophodno je da ljudi istoj oznaci pripisuju istog označitelja, što je moguće samo ukoliko je neko odrastao okružen jezikom i konvencijom naučio te označitelje. Piter Stilman Mlađi, pošto nije imao jezički uticaj, izmislio je reči koje samo on razume, to jest, za koje jedino on zna označitelja. Mrak u kojem je on odrastao predstavlja društvenu izolovanost i nepoznavanje jezika. Međutim, to nepoznavanje istovremeno predstavlja i Piterovu nevinost, i otuda belina njegovog celog lika. On je jezički neiskvaren i najbliži božanskom jeziku odnosno jeziku u kojem su veze između označenog i označitelja prirodne. Reči koje Piter smišlja su „čiste" upravo zbog takve prirode znaka, dok je u stvarnosti slučaj da ne postoji prirodna veza između označitelja i označenog već samo društveni dogovor.

Roman se završava u istoj sobi u kojoj zaplet počinje, sa Kvinom u mraku na podu sobe Pitera Stilmana Mlađeg. Stvara se pun krug naracije ne samo na planu prostora već i u tome što pravi Pol Oster postaje opsednut Kvinom isto kao što je on bio opsednut Stilmanom. Započinje se nova misterija, nova potraga, što pokazuje nemogućnost da se dođe do konačnih rešenja u pitanju jezika i teksta. „Grad je sad već bio potpuno beo, a sneg je i dalje padao, kao da nikada neće prestati" (Auster 2017: 119). Belina grada, poput beline Pitera Stilmana Mlađeg, označava čistotu i nevinost, svet otvoren za nove mogućnosti, nova tumačenja i nove priče. Ali, ujedno označava i odsustvo - Stilmana, Kvina, nade za pravom reformom jezika, nade za ponovnim ujedinjenjem znaka.

U ovom romanu autor uobličava poststrukturalističke teorije o prirodi i funkciji jezika, kao i ulozi koju jezik ima u ljudskom životu. U tom smislu možemo posmatrati Danijela Kvina kao figuru koja je reprezentacija poststrukturalizma - fragmentaran znak, bez fiksnog središta, uvek u pokretu, nejasnog identiteta i značenja koje se uvek odlaže. Piter Stilman Mlađi predstavlja jezički ideal i lingvističku realizaciju utopije. Piter Stilman Stariji je strukturalista koji očajnički želi da uspostavi red koji je postojao u strukturalizmu i da izvrši reformu jezika u pokušaju da se vrati na stari jezički poredak. Poput Kvina, on se oseća nesnađenim u poststrukturalističkom prostoru koji ga okružuje, ali je razlika između njih ta što je Stilman pokušao to da promeni, dok je Kvin prihvatio stanje stvari i prepustio se ovom tekstualnom univerzumu. 


\section{LITERATURA}

Derrida, J. 1973. Difference. U Speech and Phenomena and Other Essay's on Husserl's Theory of Signs. Evanston: Northwestern University Press, 129-160.

Derida, Ž. 1976. 0 gramatologiji (prev. Lj. Šifler Premec). Sarajevo: Veselin Masleša.

Derida, Ž. 2007. Struktura, znak i igra u diskurzu humanističkih znanosti. U Pisanje $i$ razlika (prev. V. Mikšić). Sarajevo: Šahinpašić, 297-311.

Džejmson, F. 1974. Projekcija strukturalista (prev. G. B. Todorović). U M. Pervić (ur.) Marksizam, strukturalizam, istorija, struktura. Beograd: Nolit, 346-364.

Džejmson, F. 2012. Postmodernizam ili kulturna logika kasnog kapitalizma. (prev. I. Strnčević). U J. Đorđević (ur.) Studije kulture. Beograd: Službeni glasnik, 489-528.

Fuko, M. 1971. Riječi i stvari (prev. N. Kovač). Beograd: Nolit.

Hačion, L. 1996. Poetika postmodernizma: istorija, teorija, fikcija (prev. V. Gvozden i Lj. Stanković). Novi Sad: Svetovi.

Harvey, D. 1989. The Condition of Postmodernity. Oxford: Blackwell.

Kaler, Dž. 1990. Strukturalistčka poetika (prev. M. Mint). Beograd: Srpska književna zadruga.

Lakan, Ž. 1986. XI seminar: Četiri temeljna pojma psihoanalize (prev. M. Vujanić-Lednicki). Zagreb: Naprijed.

Lojanica, M. 2012. Njujorška trilogija: jezik, želja, apokatastazis. U D. Bošković (ur.) EGZIL(ANTI): književnost, kultura, društvo. Kragujevac: Filološko-umetnički fakultet, 167-178.

Milić, N. 2005. A dekonstrukcije: la différance, pisanje, Derida i „mi”. U P. Bojanić (ur.) Žak Derida u odjecima. Beograd: Institut za filozofiju i društvenu teoriju, 29-35.

Oster, P. 2017. Njujorška trilogija (prev. I. Đurić Paunović). Beograd: Geopoetika. Sosir, F. D.-1969. Opšta lingvistika (prev. S. Marić). Beograd: Nolit.

\section{SUMMARY}

\section{CRISIS OF REPRESENTATION: THE SEARCH FOR LANGUAGE IN PAUL AUSTER'S CITY OF GLASS}

The goal of the paper is to present the novel City of Glass by Paul Auster within the context of Jacques Derrida's concepts of trace and différance. We shall examine the manner in which the concept of the sign changed from the initial concept as proposed by Ferdinand de Saussure into Derrida's playful sign. Central to our analysis is the idea of the broken sign, namely, a sign in which there is a gap in signification, a break between the signified and the signifier thus leading to the doubling of the signifier which ultimately leads to a crisis of representation. The concepts of authorship, narration and identity are questioned in post-structuralism due to a change in perception of the text and language itself. By analyzing the textual universe of the novel, the paper aims to exemplify the forms in which language is presented, its function and the effect it has on the development of the characters. 
KEYWORDS: Derrida, trace, différance, language, crisis, identity, textuality, Paul Auster.

PODACI 0 ČLANKU: Originalni naučni rad Primljen: 29. 1.2020. Ispravljen: 23. 5. 2020. Prihvaćen: 27. 5. 2020. 